\title{
Evaluation of Some Coefficients for Use in Numerical Taxonomy of Microorganisms
}

\author{
B. AUSTIN AND R. R. COLWELL \\ Department of Microbiology, University of Maryland, College Park, Maryland 20742
}

Taxonomic data, obtained for 141 Enterobacteriaceae strains for which 240 unit characters were recorded, were subjected to numerical taxonomy analysis employing 36 coefficients. Clustering was by unweighted average linkage. From sorted similarity matrices, it was found that 15 coefficients, which included $S_{S M}$, $\mathrm{S}_{\mathrm{H}}, \mathrm{S}_{\mathrm{TD}}, \mathrm{S}_{\mathrm{J}}, \mathrm{S}_{\mathrm{NM}}, \mathrm{S}_{0}, \mathrm{~S}_{\mathrm{RT}}, \mathrm{S}_{\mathrm{SHD}}, \operatorname{Sin}^{-1}\left(\mathrm{~S}_{\mathrm{SM}}\right), \mathrm{S}_{\mathrm{P}}, \mathrm{S} \phi, \mathrm{S}_{\mathrm{UN} 1}, \mathrm{~S}_{\mathrm{UN} 4}, \mathrm{~S}_{\mathrm{D}}$, and $\mathrm{S}_{\mathrm{K} 2}$, provided useful discriminating properties. The coefficients $S_{H}$ and $S_{T D}$ were found to provide results indistinguishable from $S_{S M}$, and the coefficients $S_{0}$ and $S \phi$ yielded results very similar to those obtained with $\mathrm{S}_{\mathrm{SM}}$ coefficient.

The principles of numerical taxonomy are well established, and several hundred publications concerning application of numerical taxonomy have been published since 1957, when Sneath first proposed that numerical methods be used in classifying bacteria (19). Thus, the practical utility of numerical techniques for bacterial taxonomy is attested by the large number of natural taxa which have been defined according to the principles of numerical taxonomy. However, the analyses involve, principally, only two discrete coefficients of affinity, the simple matching $\left(\mathrm{S}_{\mathrm{SM}} ; 22\right)$ and the Jaccard $\left(S_{J} ; 19\right)$ coefficients. In the case of the former, the equation includes both positive and negative matches, whereas the $S_{J}$ coefficient does not include negative correlations. Other coefficients have been suggested, but these are, in general, disregarded by most workers, and hence the effectiveness of correlation equations employing coefficients other than $S_{S M}$ and $S_{J}$ in bacterial taxonomy is largely unknown. It is conceivable that there are coefficients more efficient than the $S_{J}$ and $S_{S M}$ or more economical to use, in terms of computing facilities. Some coefficients may even permit more accurate relationships to be determined between operational taxonomic units (OTUs). Comparisons of coefficients have been attempted, using data obtained for plants $(6,25)$ and soil trace elements (14), but only limited studies have been done with bacteria $(7,24)$. In a study of bacterial species isolated from the aquatic environment (7), it was found that the nature of the coefficient is important in the interpretation of data, and differences in the clustering of the OTUs were discovered attributable to the coefficient used. To evaluate the usefulness of coefficients suggested for numerical taxonomy in bacterial taxonomy and, in this regard, thereby extending an earlier study carried out by Cheetham and Hazel (4), 15 coefficients were applied in the analysis of taxonomic data for strains of Enterobacteriaceae. The results of the analyses were compared and the coefficients were ranked according to discriminating power.

\section{MATERIALS AND METHODS}

Bacterial strains. The source and history of the 141 strains of Enterobacteriaceae included in this study, and the tests used to characterize them, were published previously (18).

Coding of data. Results from the tests were reduced to 240 unit characters, with positive, negative and noncomparable results of each test recorded as " 1 ," "0," and "9," respectively. This method of coding was found to be satisfactory for all of the 15 coefficients examined in this study. The final $n \times t$ matrix comprised 141 strains and 240 unit characters (18).

Computation. The data were punched onto standard IBM computer cards and entered into the computer for analysis using the UMDTAXON 3 and NTSYS program packages on the University of Maryland UNIVAC 1108 and National Institute of Health IBM 370/165 computers, respectively. The UMDTAXON 3 is a modification and extension of a program received from P. H. A. Sneath, University of Leicester, England. The UMDTAXON 3 program includes features of GTP-2, a numerical taxonomy program prepared by one of us (R. R. C.). NTSYS was made available by F. J. Rohlf, University of New York, Stony Brook, N. Y.

The 15 coefficients, with useful discriminating properties, compared in this study are listed in Table 1 . An additional 16 coefficients, including $\mathrm{S}_{\mathrm{K} 1}(13), \mathrm{S}_{(\mathrm{TD}) 2}, \mathrm{~S}_{(\mathrm{SID})}, \mathrm{S}_{(\mathrm{SD})^{2}}$, and $\mathrm{S}_{(\mathrm{SHD})^{2}}(19), \mathrm{S}_{\mathrm{UN} 2}$, $\mathrm{S}_{\mathrm{UN} 3}, \mathrm{~S}_{\mathrm{UN} 5}, \mathrm{~S}_{\mathrm{RR}}$, and $\mathrm{S}_{\mathrm{Y}}(22)$, and $\operatorname{Sin}^{-1}\left(\mathrm{~S}_{\mathrm{J}}\right), 1 / \mathrm{S}_{\mathrm{J}^{-1}}, 1 /$ $\mathrm{S}_{\mathrm{SM}^{-1}}, \operatorname{root}\left(1-\mathrm{S}_{\mathrm{J}}\right), \operatorname{root}\left(1-\mathrm{S}_{\mathrm{SM}}\right),-\log _{2}\left(\mathrm{~S}_{\mathrm{RT}}\right),(\mathrm{ad}-\mathrm{bc})^{2}$, $\bmod (a d-b c), S \chi^{2}$, and root $\left(S_{\chi^{2}}\right)$, which are contained on the UMDTAXON 3 program, were evaluated but found to be not helpful in terms of discriminating ability. These 16 coefficients were excluded from further consideration in this study. Clustering 
TABLE 1. Coefficients, with useful discriminating properties, included in the study and applied to the analysis of the bacterial strain data

\begin{tabular}{|c|c|c|c|}
\hline Coefficient & Abbreviation & Equation $^{a}$ & Reference \\
\hline Simple matching & $\mathrm{S}_{\mathrm{SM}}$ & $\frac{a+d}{a+b+c+d}$ & 22 \\
\hline Hamann & $\mathrm{S}_{\mathrm{H}}$ & $\frac{a+d-b-c}{a+b+c+d}$ & 11 \\
\hline Total difference & $\mathbf{S}_{\mathrm{TD}}$ & $\frac{b+c}{a+b+c+d}$ & 20 \\
\hline Jaccard & $\mathrm{S}_{J}$ & $\frac{a}{a+b+c}$ & 12 \\
\hline Nonmetric & $\mathrm{S}_{\mathrm{NM}}$ & $\frac{b+c}{2 a+b+c}$ & 21 \\
\hline Ochiai & $\mathrm{S}_{0}$ & $\frac{a}{\sqrt{(a+b)(a+c)}}$ & 15 \\
\hline Rogers and Tanimoto & $\mathrm{S}_{\mathrm{RT}}$ & $\frac{a+d}{a+d+2(b+c)}$ & 17 \\
\hline Pattern difference & $\mathbf{S}_{\mathrm{SHD}}$ & $\frac{2 \sqrt{b c}}{a+b+c+d}$ & 20 \\
\hline $\begin{array}{l}\text { Angular transformation of } \\
\mathrm{S}_{\mathrm{SM}} \times 2 / \pi\end{array}$ & $\operatorname{Sin}^{-1}\left(S_{S M}\right)$ & $0.637 \times \arcsin \left[\sqrt{\frac{a+d}{a+b+c+d}}\right]$ & \\
\hline Pearson & $\mathbf{S}_{\mathbf{P}}$ & $\frac{(a d-b c)^{2}}{(a+b)(a+c)(b+d)(c+d)}$ & 16 \\
\hline Guilford & $\mathbf{S} \phi$ & $\frac{a d-b c}{\sqrt{(a+b)(a+c)(b+d)(c+d)}}$ & 10 \\
\hline \multirow[t]{2}{*}{ Unnamed } & $\mathrm{S}_{\mathrm{UN} 1}$ & $\frac{2(a+d)}{a+b+c+d}$ & 23 \\
\hline & $\mathrm{S}_{\mathrm{UN} 4}$ & $1 / 4\{[a /(a+b)]+[a /(a+c)]+[d /(b+d)]+[d / d]\}$ & 23 \\
\hline Dice & $\mathrm{S}_{\mathrm{D}}$ & $\frac{2 a}{(2 a+b+c)}$ & 8 \\
\hline Kulczynski & $\mathrm{S}_{\mathrm{K} 2}$ & $1 / 2\{[a /(a+b)]+[a /(a+c)]\}$ & 13 \\
\hline
\end{tabular}

a Symbols: "a" and "d," the number of positive and negative matches, respectively; " $b$ " and "c," the number of nonmatching unit characters between OTUs.

was achieved by unweighted average linkage (22) from which sorted similarity matrices were constructed.

Comparisons between coefficients. To compare the clustering efficiency for OTUs at given similarity levels between the coefficients, a comparative index was devised: $1 / 2\left[\left(N_{0}+C_{0}\right) /\left(N_{s}+C_{s}\right)\right]$, where the number of OTUs $\left(\mathrm{N}_{0}\right)$ recovered in clusters $\left(\mathrm{C}_{0}\right)$, defined at a given similarity level, are compared to similar parameters, namely, $\mathrm{N}_{\mathrm{s}}$ and $\mathrm{C}_{\mathrm{s}}$, established for another coefficient. In this study, comparison was made to the $S_{J}$ and $S_{S M}$ coefficients. To permit a maximum comparative value of unity to be determined, when $\mathrm{C}_{0}>\mathrm{C}_{\mathrm{s}}$, the terms in the equation were inverted.

\section{RESULTS}

Clusters defined in the range of 80 to $85 \%$ similarity were selected for comparison. A representative portion of each of the sorted similarity matrices obtained from the analyses of the 141 Enterobacteriaceae strains examined for 240 unit characters has been reproduced in Fig. 1 to 3 . The diagrams shown represent two adjacent clusters defined by using the $S_{\mathrm{SM}}$ coefficient and unweighted average linkage clustering. The portions of the matrix shown in Fig. 1 to 3 illustrate differences found among results obtained by using the 15 coefficients. 

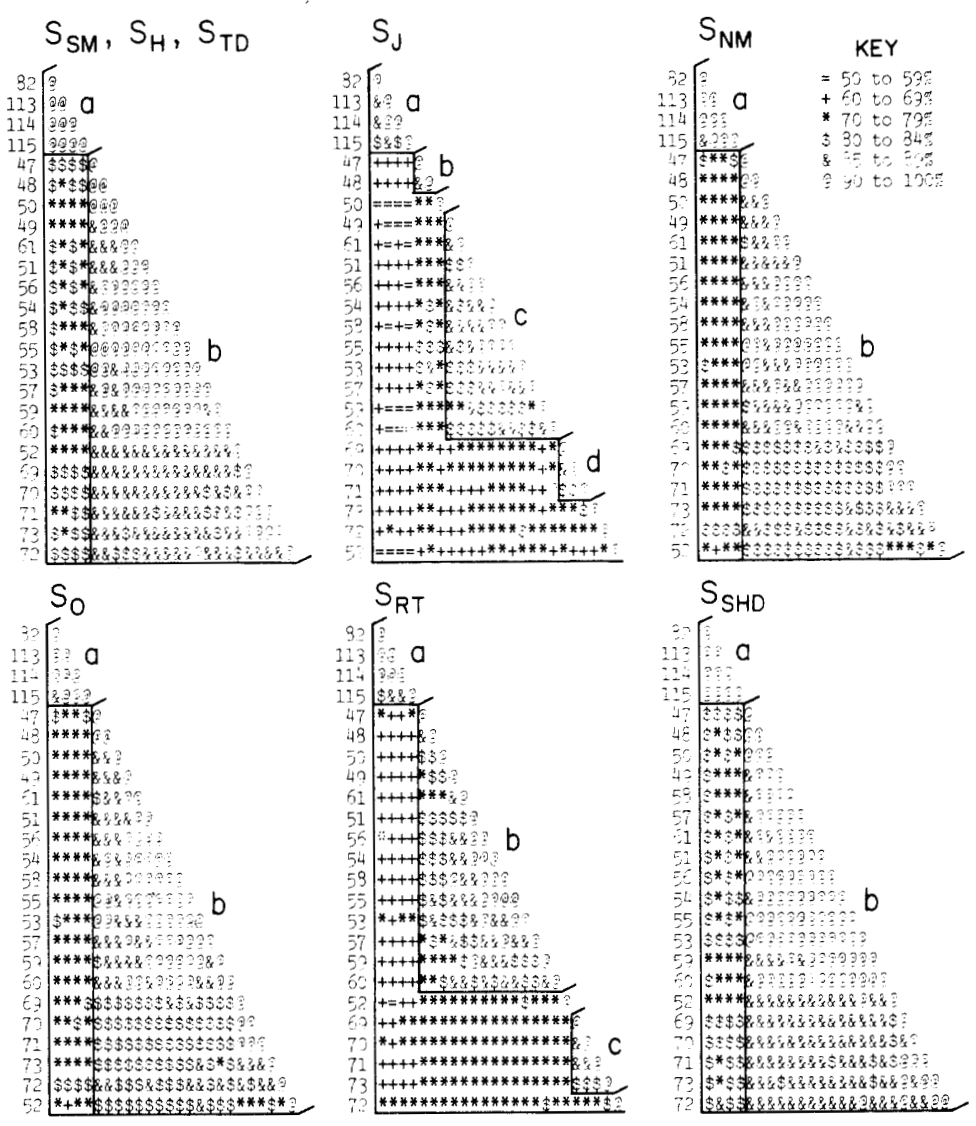

Fig. 1. Shaded diagrams representing sorted similarity matrices based on coefficients which have useful differentiating properties. Clustering was achieved by means of the unweighted average linkage technique.

Although the clustering reported here was achieved by using only the unweighted average linkage methods, other methods were also employed, including single, weighted average, highest, and complete linkage, but the results obtained were very similar and, accordingly, only results for the unweighted average linkage clustering are presented for comparative purposes. Differences obtained in the sorted similarity matrices were, therefore, a function of the coefficient and not of the clustering procedure.

In this study, by definition, good differentiation was based on formation of discrete clusters in the S-value range of 80 to $85 \%$ similarity. However, as described below, the definition of clusters may be subjective on the part of the investigator, with doubt, on occasion, as to the "best" delineation of clusters. An attempt was made, therefore, to establish standardization. For example, clusters $c, b$, and $b$, defined using the $\operatorname{Sin}^{-1}\left(S_{\mathrm{SM}}\right), \mathrm{S}_{\mathrm{RT}}$, and $\mathrm{S}_{\mathrm{P}}$ coefficients, respec- tively (Fig. 1 and 2), could be further divided into each of two subclusters, depending upon selection of the point of separation. In addition, both of the clusters $b$ and $c$, obtained with the $\mathrm{S}_{\mathrm{UN} 4}$ and $\mathrm{S}_{\mathrm{D}}$ coefficients (Fig. 2), could be combined into one larger cluster if the level of separation of the groups was lowered slightly. The clusters, as defined, serve to represent the optimum clustering for the criteria selected for the study.

Fifteen coefficients provided useful differentiating properties, when applied in conjunction with unweighted average linkage clustering. Discrete clusters were formed at the 80 to $85 \%$ similarity level. Both the $S_{H}$ and $S_{T D}$ coefficients produced results very similar to those obtained with $\mathrm{S}_{\mathrm{SM}}$ (Tables 2 and 3). Only at the lower similarity levels did discrepancies among the coefficients appear. From the comparative indices (Table 2) it is concluded that the coefficients possess a unit rating comparable to $S_{S M}$ for clusters defined at the 80 to $85 \%$ similarity 
level (Table 2). $S_{\mathrm{NM}}, \mathrm{S}_{0}$, and $\mathrm{S} \phi$ also gave results which were very similar to those of $S_{S M}$ Fig. 1 and 2; Table 2).

Another group of coefficients similar to the $S_{J}$ coefficient included $\mathrm{S}_{\mathrm{RT}}$, $\operatorname{Sin}^{-1}\left(\mathrm{~S}_{\mathrm{SM}}\right)$, and $\mathrm{S}_{\mathrm{p}}$ (Table 2), all of which included negative matches in the equations (Table 1). The other seven coefficients showed subtle differences in comparing OTUs (Fig. 1 to 3), although there were variations in both the quantitative and qualitative aspects of the clustering. The variation, in part, could be attributed to localized changes within the matrices (Fig. 1 to 3). For example, the high similarity values obtained with the $S_{S M}$ coefficient were sufficiently reduced with the $\mathrm{S}_{\mathrm{K} 2}$ analysis for four clusters to be recognized, rather than two. Similar effects were noted with the $S_{U N 4}$ and $S_{D}$ coefficients.

Efficiency of the coefficients for bacterial taxonomy. The classifications of the strains used in this study are given in Table 4. Four strains of Hafnia alvei (numbers 82, 113, 114, 115) were recovered in one homogeneous, highly related cluster regardless of which coefficient was used (Fig. 1 to 3). However, the strain of Citrobacter diversus/Levinea malonatica (number 52) clustered with Escherichia in matrices obtained using the $S_{\mathrm{SM}}, \mathrm{S}_{\mathrm{H}}, \mathrm{S}_{\mathrm{K} 2}$, and $\mathrm{S}_{\mathrm{SHD}}$ coefficients and, although removed to the bottom of the clusters obtained using the $S_{\mathrm{NM}}$, $\mathrm{S}_{\mathrm{o}}, \mathrm{S}_{\mathrm{UN} 1}, \mathrm{~S}_{\mathrm{UN} 4}, \mathbf{S}_{\mathrm{D}}, \mathrm{S}_{\mathrm{K} 2}$, and $\mathbf{S} \phi$ coefficients, the strain remained associated with $E$. coli at a similarity level $>80 \%$. Only with the $\mathrm{S}_{\mathrm{J}}, \mathrm{S}_{\mathrm{RT}}$, $\operatorname{Sin}^{-1}\left(S_{S M}\right)$, and $S_{P}$ coefficients was this strain found to be separated from the other taxa.

The remaining OTUs comprised strains of $E$. coli (Table 4) and, using the $\mathrm{S}_{\mathrm{SM}}, \mathrm{S}_{\mathrm{SHD}}, \mathrm{S}_{\mathrm{TD}}, \mathrm{S}_{\mathrm{NM}}$, $\mathrm{S}_{0}, \mathrm{~S}_{\mathrm{UN} 1}$, and $\mathbf{S} \phi$ coefficients, these strains were recovered in one cluster defined at 80 to $85 \%$ similarity. However, it can be seen that, with the $S_{J}$ coefficient (Fig. 1), three clusters were in fact recognized and four strains were not clustered at this level of similarity. Thus, with negative matches removed from the calculation, it would appear that $E$. coli comprises a somewhat heterogeneous taxon. Similarly, in
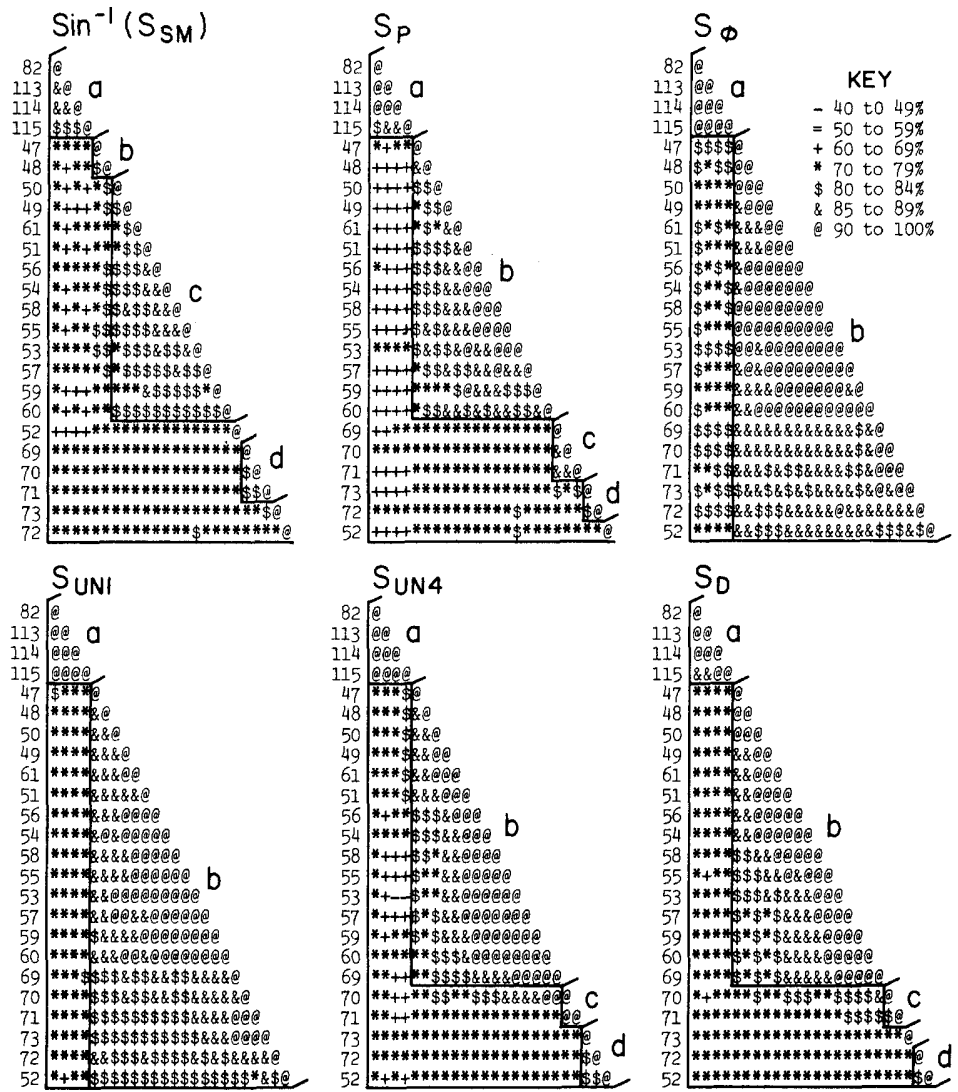

FIG. 2. Shaded diagrams representing sorted similarity matrices based on coefficients with useful differentiating properties. Clustering was achieved by means of the unweighted average linkage technique. 
the case of the $S_{R T}$ coefficient, whereby differences between OTUs are weighted, $S_{D}$ and $S_{K 2}$, in which the negative matches between OTUs are eliminated, and $\mathrm{S}_{\mathrm{UN} 4}, \operatorname{Sin}^{-1}\left(\mathrm{~S}_{\mathrm{SM}}\right)$, and $\mathrm{S}_{\mathrm{P}}$, in which both positive and negative matches between OTUs are included, the strains of $E$. coli were recovered in several clusters. The trends observed for other strains were recorded but, because of space limitations, are not presented here. It would appear from the results of this study that the $\mathrm{S}_{\mathrm{J}}, \operatorname{Sin}^{-1}\left(\mathrm{~S}_{\mathrm{SM}}\right)$, and $\mathrm{S}_{\mathrm{p}}$ coefficients are efficient for bacterial taxonomy, permitting

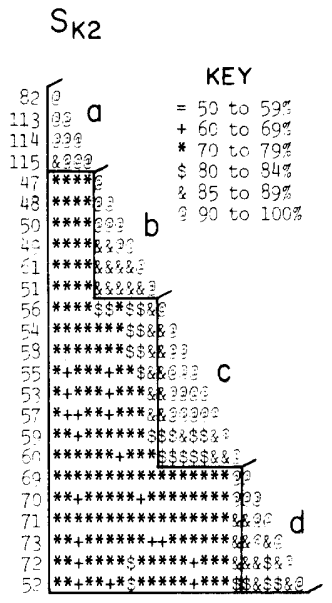

FIG. 3. Shaded diagram representing a sorted similarity matrix based on the $S_{K 2}$ coefficient. Clustering was achieved by means of the unweighted average linkage technique. taxa to be recovered as separate clusters. When these coefficients were applied to the analysis of $C$. diversus/L. malonatica, the strain was separated from the other OTUs and the $E$. coli strains were recovered in subgroups.

\section{DISCUSSION}

In general, coefficients employed in numerical taxonomy studies of bacteria are restricted

TABLE 2. Index for coefficients compared with the $S_{J}$ and $S_{S M}$ coefficients $^{a}$

\begin{tabular}{|c|c|c|c|c|}
\hline \multirow{3}{*}{ Coefficient } & \multicolumn{4}{|c|}{ Clusters defined at: } \\
\hline & \multicolumn{2}{|c|}{80 to $85 \%$} & \multicolumn{2}{|c|}{$70 \%$} \\
\hline & $\begin{array}{c}\mathrm{S}_{\mathrm{SM}} \text { simi- } \\
\text { larity in- } \\
\text { dex }(\%)\end{array}$ & $\begin{array}{c}\mathrm{S}_{\mathrm{J}} \text { simi- } \\
\text { larity in- } \\
\text { dex }(\%)\end{array}$ & $\begin{array}{c}\mathrm{S}_{\mathrm{SM}} \text { simi- } \\
\text { larity in- } \\
\text { dex }(\%)\end{array}$ & $\begin{array}{l}\mathrm{S}_{\mathrm{J}} \text { simi- } \\
\text { larity in- } \\
\text { dex }(\%)\end{array}$ \\
\hline $\mathrm{S}_{\mathrm{SM}}$ & 100 & 30 & 100 & 25 \\
\hline $\mathrm{S}_{\mathrm{H}}$ & 100 & 50 & 71 & 33 \\
\hline $\mathrm{S}_{\mathrm{TD}}$ & 100 & 50 & 100 & 25 \\
\hline $\mathbf{S}_{\mathrm{J}}$ & 50 & 100 & 23 & 100 \\
\hline $\mathbf{S}_{\mathrm{NM}}$ & 80 & 60 & 64 & 42 \\
\hline $\mathrm{S}_{\mathrm{o}}$ & 90 & 50 & 41 & 50 \\
\hline $\mathrm{S}_{\mathrm{RT}}$ & 50 & 80 & 34 & 73 \\
\hline $\mathrm{S}_{\mathrm{SHD}}$ & 70 & 40 & 100 & 25 \\
\hline $\operatorname{Sin}^{-1}\left(S_{S M}\right)$ & 50 & 90 & 11 & 57 \\
\hline $\mathrm{S}_{\mathrm{P}}$ & 50 & 90 & 28 & 76 \\
\hline $\mathbf{S} \phi$ & 90 & 50 & 100 & 25 \\
\hline $\mathbf{S}_{\mathrm{UN} 1}$ & 60 & 46 & 55 & 17 \\
\hline $\mathrm{S}_{\mathrm{UN} 4}$ & 71 & 40 & 66 & 33 \\
\hline $\mathrm{S}_{\mathrm{D}}$ & 64 & 43 & 65 & 44 \\
\hline $\mathrm{S}_{\mathrm{K} 2}$ & 64 & 43 & 67 & 45 \\
\hline
\end{tabular}

a Clustering was achieved by means of the unweighted average linkage technique.

TABLE 3. Effectiveness of the coefficients in terms of delineation of meaningful clusters ${ }^{a}$

\begin{tabular}{|c|c|c|c|c|c|c|}
\hline \multirow[b]{2}{*}{ Coefficient } & \multicolumn{3}{|c|}{80 to $85 \%^{b}$} & \multicolumn{3}{|c|}{$70 \% b$} \\
\hline & $\begin{array}{c}\text { No. of clus- } \\
\text { ters }\end{array}$ & $\begin{array}{l}\text { Recovery of } \\
\text { OTUs in clus- } \\
\text { ters }(\%)\end{array}$ & $\begin{array}{l}\text { No. of clusters } \\
\text { containing } \geq 2 \% \\
\text { of the strains }\end{array}$ & $\begin{array}{l}\text { No. of clus- } \\
\text { ters }\end{array}$ & $\begin{array}{l}\text { Recovery of } \\
\text { OTUs in clus- } \\
\text { ters }(\%)\end{array}$ & $\begin{array}{c}\text { No. of clusters } \\
\text { containing } \geq 2 \% \\
\text { of the strains }\end{array}$ \\
\hline $\mathrm{S}_{\mathrm{SM}}$ & 12 & 96 & 9 & 2 & 100 & 2 \\
\hline $\mathrm{S}_{\mathrm{H}}$ & 12 & 96 & 9 & 3 & 98 & 3 \\
\hline $\mathrm{S}_{\mathrm{TD}}$ & 12 & 96 & 11 & 2 & 100 & 2 \\
\hline $\mathrm{S}_{\mathrm{J}}$ & 24 & 80 & 17 & 13 & 94 & 11 \\
\hline $\mathrm{S}_{\mathrm{NM}}$ & 15 & 96 & 13 & 5 & 99 & 3 \\
\hline $\mathrm{S}_{\mathrm{O}}$ & 13 & 95 & 11 & 6 & 98 & 4 \\
\hline $\mathrm{S}_{\mathrm{RT}}$ & 21 & 84 & 16 & 9 & 96 & 9 \\
\hline $\mathbf{S}_{\mathrm{SHD}}$ & 9 & 96 & 9 & 2 & 100 & 2 \\
\hline $\operatorname{Sin}^{-1}\left(\mathbf{S}_{\mathrm{SM}}\right)$ & 21 & 81 & 16 & 6 & 96 & 6 \\
\hline $\mathrm{S}_{\mathrm{P}}$ & 21 & 84 & 16 & 9 & 95 & 9 \\
\hline $\mathbf{S} \phi$ & 11 & 96 & 11 & 1 & 100 & 1 \\
\hline $\mathrm{S}_{\mathrm{UN} 1}^{\top}$ & 15 & 99 & 10 & 1 & 100 & 1 \\
\hline $\mathrm{S}_{\mathrm{UN} 4}$ & 37 & 90 & 13 & 6 & 100 & 5 \\
\hline $\mathrm{S}_{\mathrm{D}}$ & 36 & 83 & 11 & 14 & 99 & 8 \\
\hline $\mathrm{S}_{\mathrm{K} 2}$ & 38 & 84 & 12 & 13 & 100 & 8 \\
\hline
\end{tabular}

${ }^{a}$ Clustering was achieved by means of the unweighted average linkage technique.

${ }^{b}$ Level of clustering. 
TABLE 4. Strains included in sorted similarity matrices (shaded diagrams, Fig. 1-3)

\begin{tabular}{llll}
\hline \multicolumn{1}{c}{ Lab reference no. } & $\begin{array}{c}\text { Identification of strains by Sakazaki } \\
\text { et al. (18) }\end{array}$ & Received as: & Source \\
\hline $\begin{array}{l}47,48,49,50,51,53,54,55,56, \\
57,58,59,60,61,69,70,71,72,\end{array}$ & Escherichia coli & E. coli & $\begin{array}{c}\text { R. Saka- } \\
\text { zaki }^{a}\end{array}$ \\
73 & $\begin{array}{c}\text { Citrobacter diversus/Levinea } \\
\text { malonatica } \\
\text { Hafnia alvei }\end{array}$ & L. malonatica & ATCC $^{b}$ \\
$82,113,114,115$ & H. alvei & $\begin{array}{c}\text { R. Saka- } \\
\text { zaki }\end{array}$ \\
\hline
\end{tabular}

${ }^{a}$ R. Sakazaki, National Institute of Health, Tokyo.

${ }^{b}$ American Type Culture Collection, Rockville, Md.

to the $S_{S M}$ and $S_{J}$ coefficients, with the exception of $\mathrm{S}_{\mathrm{RT}}$, which has been used in the classification of soil bacteria, and $\mathbf{S}_{\mathrm{SHD}}$, which has been used in the classification of yellow-pigmented bacteria isolated from the phylloplane (9). In the present study it has been shown that a wide range of coefficients can be used successfully in numerical taxonomy studies of bacteria, with the coefficients $\operatorname{Sin}^{-1}\left(S_{S M}\right)$ and $S_{P}$ being well suited for this purpose. The list of coefficients useful in numerical taxonomy of bacteria can be expanded to include $\mathrm{S}_{\mathrm{NM}}, \mathrm{S}_{0}, \mathrm{~S}_{\mathrm{H}}, \mathrm{S}_{\mathrm{RT}}, \mathrm{S}_{\mathrm{SHD}}, \mathrm{S}_{\mathrm{TD}}$, $\mathrm{S}_{\mathrm{UN} 1}, \mathrm{~S}_{\mathrm{UN} 4}, \mathrm{~S}_{\mathrm{D}}, \mathrm{S}_{\mathrm{K} 2}$, and $\mathrm{S} \phi$. Although it has been reported that $S_{R T}$ and $S_{D}$ are monotonic with $S_{S M}$ and $S_{J}$, respectively (21), the results from the present study do not confirm this earlier conclusion. In fact, from the results of this study it is concluded that $S_{H}$ and $S_{T D}$ are indistinguishable from $S_{\mathrm{SM}}$, whereas $\mathrm{S}_{\mathrm{O}}$ and $\mathrm{S} \phi$ approximate the $S_{J}$ coefficient. These observations were confirmed using a separate data set collected for petroleum-degrading bacteria isolated from the aquatic environment (1).

When comparing coefficients it is necessary to determine whether negative matches should be considered (21) and, for this reason, we have analyzed data obtained in this study using both the $S_{S M}$ and $S_{J}$ coefficients. The Jaccard coefficient $\left(S_{J} ; 12\right)$ is the most widely used coefficient and excludes negative matches from the equation (23). The $S_{J}$ coefficient emphasizes differences between OTUs. Other coefficients have been found to be similar in this respect and include $S_{\mathrm{NM}}, S_{0}, S_{D}$, and $S_{K 2}$, all of which were shown to be especially useful in bacterial taxonomy. Certain of the coefficients, notably $\mathrm{S}_{\mathrm{K} 2}$ and $S_{0}$, have been proposed for use in taxonomic and bioassociation studies, whereas $S_{H}$, $\mathrm{S}_{\mathrm{RT}}$, and $\mathbf{S} \phi$ have been suggested for taxonomic studies, exclusively (23). The results obtained here verify, in part, these conclusions when applied to bacterial taxonomy.

Vigor and pattern statistics (20) have been shown to be valuable in bacterial taxonomy (9), when seemingly misplaced strains are re- covered in natural taxa. This study has verified the effectiveness of $\mathrm{S}_{\mathrm{TD}}$, total difference between OTUs, and $S_{\text {SHD }}$ pattern difference, although the pattern difference between the strains has not affected their natural grouping (Table 2).

The choice of coefficients remains subjective, with several coefficients clearly demonstrated to be useful in bacterial taxonomy. It is interesting to note that botanical studies have contributed significantly to the development of new coefficients and, in particular, $\mathrm{S}_{\mathrm{H}}, \mathrm{S}_{\mathrm{J}}, \mathrm{S}_{\mathrm{K} 2}$, and $S_{\mathrm{RT}}$ have been derived for such use. In contrast, $S_{D}, S_{0}$, and $S_{p}$ were formulated for zoological (15) and anthropological (16) purposes, respectively, whereas $\mathbf{S} \phi$ was derived originally for use in psychological studies. With the exception of $\mathrm{S}_{\mathrm{SM}}(22)$ and $\mathrm{S}_{\mathrm{TD}}$ and $\mathrm{S}_{\mathrm{SHD}}(20)$, the original purpose of the other four coefficients, $S_{\mathrm{NM}}$, $\operatorname{Sin}^{-1}\left(\mathrm{~S}_{\mathrm{SM}}\right), \mathrm{S}_{\mathrm{UN} 1}$, and $\mathrm{S}_{\mathrm{UN} 4}$, is not so clearly defined. The selection of an appropriate coefficient is important in numerical taxonomy, illustrated by the development of new equations, such as the recently derived coefficient for analysis of biogeographical data (2). The effectiveness of this coefficient in bacterial taxonomy awaits further study.

Economics is an important consideration in selecting or developing a coefficient for microbial systematics. In this study, evidence was obtained suggesting that some coefficients, notably $S_{D}$ and $S_{K 2}$, are more economical to use than others in terms of computer time, i.e., costs. It is concluded from this study that a wide range of coefficients can be useful in numerical taxonomy of bacteria and that the choice of coefficient need not be limited to the $S_{S M}$ and $S_{J}$ coefficients.

\section{ACKNOWLEDGMENTS}

We acknowledge receipt of National Science Foundation Grant No. DEB 72-02227 A04 for the duration of this study. Computational procedures were executed on the University of Maryland UNIVAC 1108 and National Institute of Health IBM 370/165 computers. We are grateful to these agencies for the generous resources provided. 


\section{REPRINT REQUESTS}

Address reprint requests to: Dr. R. R. Colwell, Department of Microbiology, University of Maryland, College Park, Md. 20742.

\section{LITERATURE CITED}

1. Austin, B., J. J. Calomiris, J. D. Walker, and R. R. Colwell. 1977. Numerical taxonomy and ecology of petroleum-degrading bacteria. Appl. Environ. Microbiol. 34:60-68.

2. Baroni-Urbani, C., and M. W. Buser. 1976. Similarity of binary data. Syst. Zool. 25:251-259.

3. Brisbane, P. G., and A. D. Rovira. 1961. A comparison of methods for classifying rhizosphere bacteria. J. Gen. Microbiol. 26:379-392.

4. Cheetham, A. H., and J. E. Hazel. 1969. Binary (presence-absence) similarity coefficients. J. Paleontol. 43:1130-1136.

5. Clifford, H. T., and W. Stephenson. 1975. An introduction to numerical classification. Academic Press Inc., New York.

6. Dagnelie, P. 1960. Contribution à l'étude des communautés végétales per l'analyse factorielle. Bull. Serve. Carte Phytogéogr. B 5:7-71, 93-105.

7. Delabre, M., A. Bianchi, and M. Véron. 1973. Étude critique de methodes de taxonomie numérique. Application à une classification de Bacteries Aquicoles. Ann. Microbiol. 124:489-506.

8. Dice, L. R. 1945. Measures of the amount of ecologic association between species. Ecology 26:297-302.

9. Goodfellow, M., B. Austin, and C. H. Dickinson. 1976. Numerical taxonomy of some yellow pigmented bacteria isolated from plants. J. Gen. Microbiol. 97:219233.

10. Guilford, J. P. 1942. Fundamental statistics in psychology and education. McGraw-Hill, New York.

11. Hamann, U. 1961. Merkmalbestand und Verwandtschaftsbeziehungen Farinosae. Ein Beitrag zum System der Monokotyledonen. Willdenowia 2:639-768.
12. Jaccard, P. 1908. Nouvelles recherches sur la distribution florale. Bull. Soc. Vaudoise Sci. Nat. 44:223-270.

13. Kulczynski, S. 1927. Die Pflanzenassoziationen der Pieninen. Bull. Int. Acad. Pol. Sci. Lett. Cl. Sci. Math. Nat. Ser. B 1927(suppl. 2):57-203.

14. Moore, A. W., and J. S. Russell. 1967. Comparison of coefficients and grouping procedures in numerical analysis of soil trace element data. Geoderma 1:139158.

15. Ochiai, A. 1957. Zoogeographic studies on the soleoid fishes found in Japan and its neighboring regions. Bull. Jap. Soc. Sci. Fish. 22:526-530.

16. Pearson, K. 1926. On the coefficient of racial likeness. Biometrika 18:105-117.

17. Rogers, D. J., and T. T. Tanimoto. 1960. A computer program for classifying plants. Science 132:11151118.

18. Sakazaki, R., K. Tamura, R. Johnson, and R. R. Colwell. 1976. Taxonomy of some recently described species in the family Enterobacteriaceae. Int. J. Syst. Bacteriol. 26:158-179.

19. Sneath, P. H. A. 1957. The application of computers to taxonomy. J. Gen. Microbiol. 17:201-226.

20. Sneath, P. H. A. 1968. Vigour and pattern in taxonomy. J. Gen. Microbiol. 54:1-11.

21. Sneath, P. H. A., and R. R. Sokal. 1973. Numerical taxonomy. W. H. Freeman and Co., San Francisco.

22. Sokal, R. R., and C. D. Michener. 1958. A statistical method for evaluating systematic relationships. Univ. Kansas Sci. Bull. 38:1409-1438.

23. Sokal, R. R., and P. H. A. Sneath. 1963. Principles of numerical taxonomy. W. H. Freeman and Co., San Francisco.

24. 'T. Mannetje, L. 1967. A comparison of eight numerical procedures applied to the classification of some African Trifolium taxa based on Rhizobium affinities. Aust. J. Bot. 15:521-528.

25. Williams, W. T., J. M. Lambert, and G. N. Lance. 1966. Multivariate methods in plant ecology. V. Similarity analyses and information-analysis. J. Ecol. 54:427445. 